Viacheslav Briukhovetsky: "The Idea of the Rebirth of the Kyiv-Mohyla Academy Came to Me a Year before the Breakup of the USSR..."

Conducted by: Volodymyr Panchenko

Source: Kyiv-Mohyla Humanities Journal 2 (2015): 1-10

Published by: National University of Kyiv-Mohyla Academy

http://kmhj.ukma.edu.ua/ 


\section{Viacheslav Briukhovetsky: "The Idea of the Rebirth of the Kyiv-Mohyla Academy Came to Me a Year before the Breakup of the USSR..."}

A Conversation with Viacheslav Briukhovetsky, the Honorary President of the National University of Kyiv-Mohyla Academy

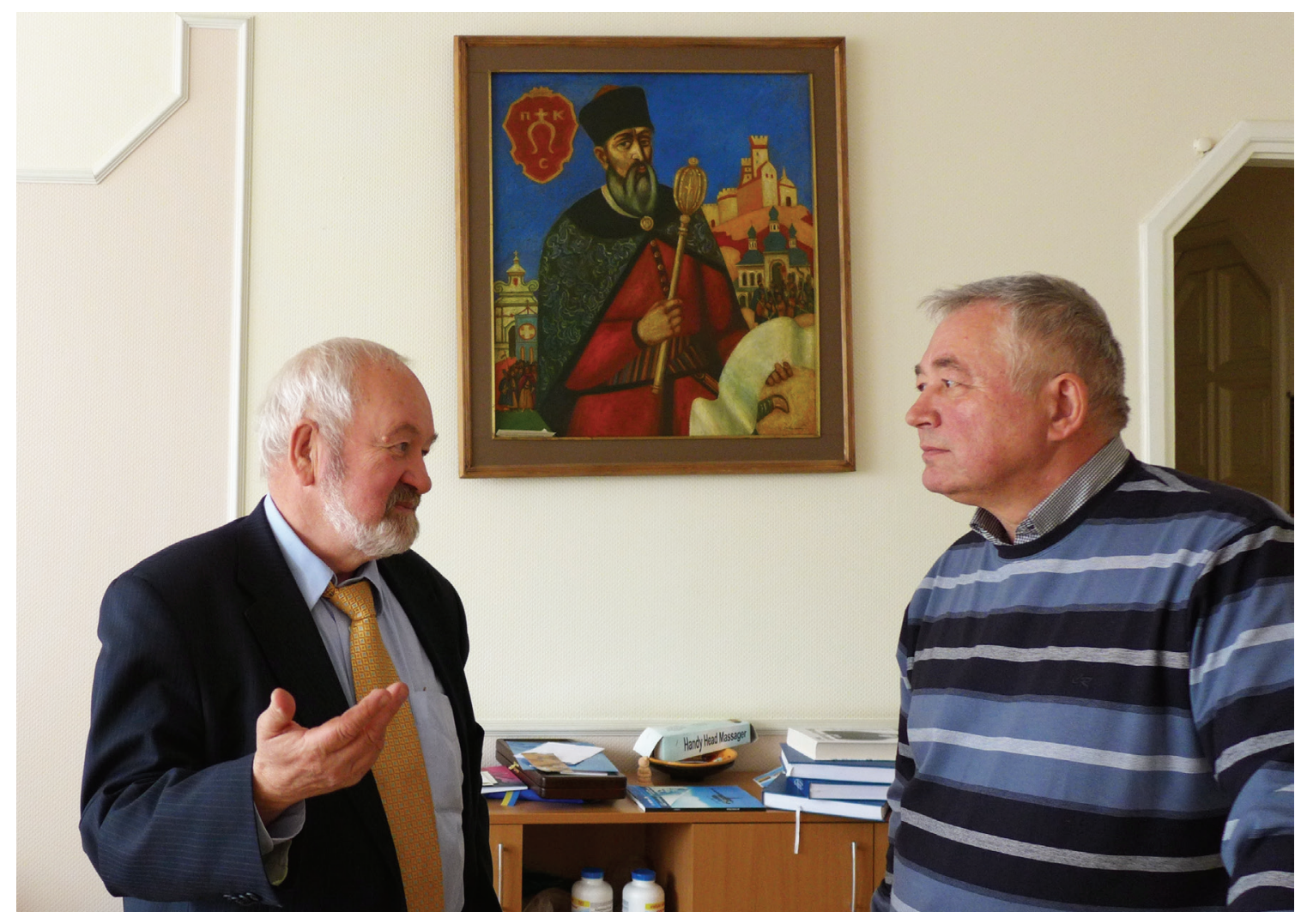

VOLODYMYR PANCHENKO: Our readers, I think, will be interested in finding out about the historical phenomenon of the Kyiv-Mohyla Academy and its beginnings. What does this phenomenon consist of?

VIACHESLAV BRIUKHOVETSKY: We should begin with the fact that like most universities of the time, the Kyiv-Mohyla Academy (KMA) had its beginnings as a school. Such was the case with Oxford and most other prominent universities that also had their beginnings as small schools. The school from which the Kyiv-Mohyla Academy emerged was the Bratsk [Brotherhood] Orthodox School of the Bratsk Monastery. Its founder was Halshka Hulevychivna, who did not form the school's academic concept, but provided land and buildings for the school (including her own domicile). The first rector was Iov Boretsky, who mapped the ideology of the school. It is more than likely that the Bratsk School was not founded in 1615. Information exists (unfortunately, no documents survive) that this could have happened in 1585 . But the first documented date is 1615 . In $163_{2}$ Petro Mohyla united the Bratsk and Lavra monastery schools 
and set the principle that the new school was not to be just an Orthodox school, but a school modelled on European Jesuit schools, those schools that the new school was to polemicize with. The situation at the time was different, and although it is often said that the Kyiv-Mohyla Academy fought for a national identity from its beginnings, such was not the case. The Academy fought for a religious identity, and its struggle was directed against the catholization of Ukraine. That was the path of the development of our education system. Because he was a graduate of a Jesuit Collegium himself, Mohyla knew its academic process; ideologically, he made it a basic principle of curricula design, etc. and transformed the united school into a collegium...

VOLODYMYR PANCHENKo: How did this institution look like in the context of European education?

VIACHESLAV BRIUKHOVETSKY: Of course, today this is very difficult to reconstruct. The correspondence that our professors maintained with professors from Europe when the Academy was still a Collegium is extant (and published). A German professor of the time wrote that the Kyiv-Mohyla Collegium was an important school, with which the Paris "Sorbonne schools" could not compete. We must make allowances for the fact that this was a German writing about French schools, but it was still a comparison in a European context. The Bratsk Collegium was known in Europe, and its education system was purely European. At the same time, Mohyla had many problems because the Orthodox clergy didn't show much enthusiasm for the system... Altogether, "education as enlightenment" and not simply the training of priests and monks was important for Petro Mohyla.

VOLODYMYR PANCHENKO: The KMA began its new history simultaneously with the history of Ukraine's independence. Was this coincidence or destiny? Sometimes it seems that the KMA's recent history is a history of "healthy adventurism." It could hardly have been reborn in the atheistic Soviet Union, as the latter part of the history of this institution was the history of the Kyiv Theological Academy (KTA)!

VIACHESLAV BRIUKHOVETSKY: The KTA acted as the successor to the KMA. This was the continuation of a centuries-old history. A resonant celebration was planned in 1915, which, however, was scaled down because of the war. In fact, about a year before the collapse of the Soviet Union the idea of reviving the KMA came to me, but I couldn't manage to get the support of the authorities. I was in the process of working on the matter when the Soviet Union collapsed. I remember walking through government corridors and the strange looks I received... It was a shame, because these were the people with whom I had created the Narodny Rukh Ukrainy [People's Movement of Ukraine]. Unfortunately, they demonstrated an inability to carry out organizational work. That is, everyone was "for" the idea, but no one did anything to help.

VOLODYMYR PANCHENKo: Perhaps the project seemed undoable to them?

VIACHESLAV BRIUKHOVETSKY: There were those who believed the project undoable, and there were those who thought why should Viacheslav Briukhovetsky be doing this? Those who were not from Rukh often asked if I was ordered to carry out the project. I remember one of our 
first live interactive television broadcasts. I remember when I said that the Academy would be reborn one viewer called, screaming: "Who ordered you to do this?" I answered: "No one, we're doing it ourselves." When the Soviet Union collapsed I realized that this was our big chance. There really was a healthy dose of "adventurism" on my part, but it was a reasoned adventure because the presidential election was ahead of us. Knowing Leonid Kravchuk personally and having conversed with him during Rukh times, I knew that he would instantly react to the idea. Moreover, he had real power as Speaker of the Verkhovna Rada. I should say that at that time other presidential hopefuls also had their eyes on the project. I don't want to name names, but I spoke with someone I respected very much who told me that every presidential candidate will support the idea! I decided I needed to raise the issue in public, in the presence of Leonid Kravchuk and other candidates for office. This was when the first Forum of the Intelligentsia, headed by Ivan Drach, was being held. I asked him to allow me to speak when Leonid Kravchuk was still at the gathering. I knew that when they finish speaking (and today this is almost always the case) they leave, they're no longer interested in what else will be said. I knew that someone from the party nomemenklatura having said his word would leave the gathering (which happened, by the way). I'm therefore very grateful to Ivan Drach for giving me the opportunity to speak when he did...

VOLODYMYR PANCHENKO: What was Leonid Kravchuk's reaction?

VIACHESLAV BRIUKHOVETSKY: When I returned to the assembly hall, Leonid Kravchuk's aide immediately went up to me and invited me to go to a waiting room during a break in proceedings. I went. Kravchuk said that he was ready: "Come to me with all the documents in a day's time." I answered: "Okay, but how will I get to see you?” Kravchuk replied: "Be at the Parliament, we'll find you." Indeed, they did find me. I went in and once again explained the meaning of the idea, and submitted our proposal. Kravchuk promised to sign the necessary authorization. Today I understand that that authorization had no legal force, but nevertheless, it was a document signed by the Chairman of the Verkhovna Rada. After that we began our work.

VOLODYMYR PANCHENKo: The rational aspect of the story is quite understandable (i.e., the idea, its grounding), but it seems to me that it had to be preceded by a strong emotional impulse. For example, visiting the Podil (lower town Kyiv. - Ed.)...

VIACHESLAV BRIUKHOVETSKY: At the time nothing could be done in the Podil (where the KMA is located), as it was the territory of a military school. I had emotional memories from my student years of Mykhailo Braichevsky conducting excursions in Kyiv. I remember the last tour he was allowed to conduct in the Podil (after which he was forbidden to do so). I was among those present. He led us to the Podil, telling us its story. I heard a lot from him, in particular that this was where the Kyiv-Mohyla Academy was located. We walked around the perimeter of the entire territory. At the time I couldn't even imagine that I would one day be conducting the affairs of the KMA and that Mykhailo Iulianovych Braichevsky would become a professor of the reborn Academy. 
Speaking of motivation, it was twofold: the first motivating factor was that after the creation of Rukh I received an invitation to teach in the United States, then after a brief return to Ukraine I was invited to Canada, where I also taught. A revolution occured in my understanding of how an education system should be built.

VOLODYMYR PANCHENKO: Teaching in the USA and Canada gave you an understanding of the future of the Academy?

VIACHESLAV BRIUKHOVETSKY: Before that I had taught a little in Ukraine at the Faculty of Journalism of Taras Shevchenko Kyiv National University and at the Institute of Culture. I looked at our students and saw that although they were all different I liked them more than American and Canadian students, who were much less motivated to learn. Of course, I don't have in mind standout students, but the average level. On the other hand, I liked their system of education. When I returned from Canada I had a conversation on a live radio broadcast with two young men who had participated in the first "Maidan" (the Student Revolution on Granite in October-November 1990). After the broadcast I decided to ask them more about how the revolution had happened. They were so enthusiastic, and I asked them: "Do the politics interfere with your studies? You're students after all, and studying is your main job. Because if you don't do well in your studies, you'll hit a roadblock." They answered: "We first need to build an independent Ukraine, then we'll study." And a fear overtook me, that this generation would be an uneducated one...

VOLODYMYR PANCHENKo: Although these protesters did become successful...

VIACHESLAV BRIUKHOVETSKY: A principle was at stake here. We don't know all of them, we know of some, and there were many of them. But the principle was such: why should we study when we need to build Ukraine. That's when I decided that I like the principle of free creative learning present at American universities, and thought why not create a university like that here? It became clear that I would unfortunately have to leave my institute and my work and occupy myself with my new project. I didn't know exactly what it was I would do and how I would do it... But, in fact, my talking with these students gave me a powerful incentive. I remember coming out and saying to myself: "Enough! If people don't receive a good education, we'll lose our state."

VOLODYMYR PANCHENKO: What else aside from the idea of free creative learning was present in this concept?

VIACHESLAV BRIUKHOVETSKY: Free creative learning, among other things, is not as present today at the Kyiv-Mohyla Academy because of legislation that restricts many things. Of course, an American university is a university where students pay, so they can choose courses for any number of years they want. In Canada I had a student who was 6o years old. He said he was happy to take one course a year. He was taking my course and slowly accumulating credits, and the following year he would obtain his degree. "It's been like this for a decade now." It's really 
possible there, you can study for ten or twenty years. There are some required courses, but the majority you can choose. I liked this because I saw that a person can freely form himself or herself. When I first went to a conference in New York dedicated to the theme of a Liberal Arts Education, there was a lot of interest in the difference between the KMA and Western or Soviet universities. And then I constructed a kind of picture to effectively visualize the differences. An American university is like a big room with many entrances and exits. A student can wander through it as desired, forming an individual curriculum, for example taking a course at any time that in our system could only be taken during the $5^{\text {th }}$ year of study. It's an individual matter, providing financial resources suffice. Studies can take 2 or 3 or many years, depending on individual capabilities and resources. A Soviet university is like a narrow corridor you enter not having to think about anything because you have a plan to fulfil and God forbid you stray from it! You'll get in the way of others. I myself went through this because even in my time I managed to have an individual plan. This was uncomfortable for everyone. But it gave me freedom.

VOLODYMYR PANCHENKO: But made life difficult for professors...

VIACHESLAV BRIUKHOVETSKY: Yes. I've heard that conflicts even arose. Professors would say to each other that Viacheslav Briukhovetsky attends my classes and not yours. That was a major issue.

VOLODYMYR PANCHENKO: ... and mostly likely a stimulus?

VIACHESLAV BRIUKHOVETSKY: Of course. In short, a Soviet university is a narrow corridor, where you follow the student ahead of you and behind you is another student. You can't stop, you can't turn left or right, you simply continue forward. Having passed through, if you've done well, you're handed a diploma. That's it. Whether you knew what you have studied is immaterial. We then realized that to build a university modelled on an American one "in a large room" was impossible, because we had neither the money, nor the tradition. So we built something like a triangle. At least it was like that at the beginning. At the basic level (the initial two years), students learned together, and it was easy to move from one faculty to another (this is more difficult today because certain conditions exist that we cannot overcome). In time possibilities began to narrow and specialization became a requirement. Narrow specialization of the kind that existed in the Soviet Union began at the masters level, where if for example philosophy was being studied, biochemistry wasn't an option as narrow specialization was to be maintained.

That was, in fact, the conceptual idea, to create such a university. The idea remained in force for a number of years, perhaps 10, until restrictions that exist to this day were introduced. I don't think it's right, but that's how it is.

First, I managed then to ensure that we were directly subordinated to the Cabinet of Ministers of Ukraine. That was wrong, I absolutely agree with you, I was repeatedly told: "You have to leave us, we don't have the people to lead and manage you." I managed to hold on and would say: "Okay, if you transfer us, I'll declare a hunger strike the following day, organize a press 
conference and say that you're shutting down the Kyiv-Mohyla Academy." As a result, no one wanted to talk to me about this.

VOLODYMYR PANCHENKO: Such situations seem possible only at the junction of eras!

VIACHESLAV BRIUKHOVETSKY: Of course. Which is why, for example, when I came to the Cabinet of Ministers and said things should be like this or like that the answer was that the law did not provide for that. My counter-argument was that the law may not, but that a Magna Charta Universitatum exists. The poor Soviet officials had no inkling of its existence and helplessly shrugged: "Well, if that's the case..."

VOLODYMYR PANCHENKO: I also remember this atmosphere of great uncertainty. Everything old has seemingly disappeared, or if it did exist, it was a formal existence.

VIACHESLAV BRIUKHOVETSKY: Of course, it was only possible to accomplish something at that time. Two years after that or the year before it would have been impossible. We were fortunate because in two years no one would have given us that land or allowed us that kind of freedom.

VOLODYMYR PANCHENKO: Such are "the winds of change"! If I may ask another question about another important strategic idea, that being the transformation of a teaching institution into a teaching and research institution. How successful were you on this account?

VIACHESLAV BRIUKHOVETSKY: I think it's good that, at least in the American and Canadian higher education systems, research is conducted at universities and not at an Academy of Sciences (which, incidentally, does not exist there). And a significant portion of the workload of a professor there is dedicated to research work, which is not the case with us. At first we positioned ourselves as a teaching and research institution. Then, toward the end of my tenure as President I realized that we needed to position ourselves differently. In our second strategic plan, we decided that we were no longer a teaching and research institution but rather a research and teaching institution.

We managed to accomplish some basic things, but until the law provides for a professor conducting research work, we cannot move further ahead in this direction. What is the essence of the matter? If a professor only teaches, it becomes difficult to keep abreast of advancements in his or her field. This is especially true for our universities, where because of heavy teaching loads professors have little time to spend in libraries or even on the Internet. The issue is that a university cannot be a research institution if its professors aren't involved in research. You well know that in our time (and even today), there are many professors who simply don't publish. To a certain extent that's understandable, because little time is available for research, especially today because of the difficult financial situation.

VOLODYMYR PANCHENKo: Somewhere in the early 2000 s you as President set a goal of getting on the list of the world's best 500 universities. 
Came to Me a Year before the Breakup of the USSR..."

VIACHESLAV BRIUKHOVETSKY: To be honest, perhaps that was a bit adventurous too, and the goal I set was to get on the best 50 list, not the best 500 list. But okay, let's say 500 . I believe it to be entirely possible and I know how to accomplish this. Incidentally, not that much was needed to accomplish the goal. More freedom and research funding were necessary. We sometimes underestimate the level of our professors, and especially today another generation is emerging with a knowledge of languages. Our generation was different.

VOLODYMYR PANCHENKO: Is being on the top 50 list somehow associated with the general situation in the country, or not?

VIACHESLAV BRIUKHOVETSKY: Apparently yes, because the top $5^{\circ}$ list consists of universities from highly developed countries, mainly America, Britain, France, and Japan, because they are well financed. Another indicator is the number of Nobel Prize laureates teaching at a university. How can we speak of Nobel Prize laureates without financing?.. They all go to America, which is full of immigrants from Ukraine who are Nobel Prize laureates, mostly ethnic Jews, but nevertheless from Ukraine. And not only ethnic Jews.

VOLODYMYR PANCHENKo: Possibilities still exist.

VIACHESLAV BRIUKHOVETSKY: Possibilities still exist. I believe that sooner or later we'll accomplish this, first of all, when the war is over, and a normal process of rebuilding can finally begin.

VOLODYMYR PANCHENKO: I would now like to ask about a paradoxical situation in our education system as a whole. I have in mind the external independent testing system, which seems to have taken a turn for the worse at the Kyiv-Mohyla Academy... What is your opinion about this?

VIACHESLAV BRIUKHOVETSKY: I publicly addressed this question numerous times and because of it we even had a falling out with the then Minister of Education (Ivan Vakarchuk. - Ed.). I publicly explained the difference to him. We were the second to introduce testing, a year after Lviv University had done so. I travelled to Lviv to study their experience. To be honest, I just borrowed their encryption system, which we improved on, but at first we did exactly as they had done. In one of his articles Ivan Vakarchuk openly stated that in order to reduce the possibility of corruption written tests had replaced oral exams. In fact, it was like that. Exams where a teacher immediately grades a student were replaced by tests on which unfair grading was more difficult. We did things differently. Our task was not to simply replace oral exams with written tests, but to reorient these tests so that they would assess not the applicant's sum of knowledge, but instead gauge their way of thinking and whether the applicant is capable of thinking. Traditional tests are conducted in a manner where the applicant is tested in mathematics today, English tomorrow and so on. We had a single test that consisted of eight modules: Ukrainian, English, physics, mathematics, history, etc. Everyone took the same test, only the results were (machine) tallied separately at each faculty. At first colleagues were 
indignant, saying: "Why should literature students be tested in mathematics, which they don't know anyway?" My answer was that some of them do know math, some better than others, and that should give them an advantage, because mathematics is an important discipline that teaches one to think. Eventually all the deans who at first had protested came on board. In time I understood that this system works. I even visited Harvard University to study their admission system, where everything is based on testing. First of all, they have a number of tests, second, each university selects a combination of tests and third, their tests differ in orientation. But I'm convinced that in time our Mohyla testing system will return, albeit in a modified form. I can even admit that I have a test ready and waiting in my computer, and if tomorrow or several days before the commencement of an entrance campaign I'm asked to conduct the testing, I'll sit down, make a few changes, and proceed with the tests.

VOLODYMYR PANCHENKo: There is a mechanism for this, you need to influence the Minister of Education. A Minister has the right to initiate legislation and may amend laws and regulations.

VIACHESLAV BRIUKHOVETSKY: I have proposed this to the current Minister. I understand that to accomplish this under the current conditions existing in the country is very difficult. I proposed the same experiment to Serhiy Kvit that I had to Ivan Vakarchuk. The experiment would consist of giving us 5 years to compare results, then we could draw conclusions. Incidentally, we did embark on such a comparison a while back...

VOLODYMYR PANCHENKO: There were issues at the time, and if I'm not mistaken, a number of applicants took their cases to the prosecutor's office.

VIACHESLAV BRIUKHOVETSKY: Yes, they were issues, but nothing became of them because everything was done according to procedure and the law. I said, give us five years, then we'll analyse everything and deliver a result.

VOLODYMYR PANCHENKO: Changes to legislation are not even necessary here, what is needed is simply a document from the Ministry of Education allowing the experiment. The only thing is that applicants may be against this.

VIACHESLAV BRIUKHOVETSKY: Let them go elsewhere if they don't like it here. This means that this is not their kind of university. But no one wants to support the experiment, although it would be very interesting because we'd have the opportunity to compare.

VOLODYMYR PANCHENKo: Viacheslav Stepanovych, we now have the third President of the KyivMohyla Academy. If you were in his place, what goals would you set for yourself and the University?

VIACHESLAV BRIUKHOVETSKY: I'd confront the question that we must first of all attempt to become a true research and teaching institution. Today there is much more reason to understand that this is possible because today we have a new generation. That is, in comparison with the generation that created the Kyiv-Mohyla Academy, among whom very few people spoke 
English, who I could count on the fingers of one hand. Today all our young teachers to a greater or lesser extent, some brilliantly, are fluent in English.

VOLODYMYR PANCHENKO: This means that the education system in general has improved...

VIACHESLAV BRIUKHOVETSKY: Yes, of course, both schools and universities. What existed then, other than suspicion for desiring to know English? Meaning, if you know English, you're planning to leave. The basic idea is that without this we'll never be on any top list. We need to give people the opportunity to conduct research. A person who is engaged in research brings new knowledge to students from primary sources. Someone not engaged in research teaches as they did a decade ago. That's how they work abroad, America in particular, where the professor has the right to teach what he or she sees fit. This was very difficult to understand. It's very important at the masters level, and development is impossible without it.

VOLODYMYR PANCHENKO: For a professor this implies a high level of freedom along with a high degree of responsibility...

VIACHESLAV BRIUKHOVETSKY: Because a professor is responsible for his or her students. If a professor is weak, students won't take his or her courses. There students enrol in courses and professors compete for students. A professor is not just given a group of students to teach. It's approximately what happens in our optional courses. If students enrol the course takes place, without enrolment it doesn't.

VOLODYMYR PANCHENKO: I remember a situation when you proudly quoted Russian expert Inokenti Andreev, who acknowledged that a project such as NaUKMA represents a triumph for Ukraine and a defeat for Russia. Please comment on this remark.

VIACHESLAV BRIUKHOVETSKY: I did say this, but without using the word "defeat." This was an article by political scientist Inokenti Andreev, in which he described the situation of competition in the former Soviet republics and found that the Kyiv-Mohyla Academy represents a significant threat to Russia's influence over Ukraine because it trains students who need absolutely no translations as they read primary sources in the original, which leads them away from the idea of a "Russian World" [russkii mir]. And this is already a threat. I don't remember if the term "Russian World" was used, perhaps it was not, but the idea was there. Which is why I. Andreev insists that the influence the Kyiv-Mohyla Academy has on Ukrainian society needs to be curtailed as soon as possible.

VOLODYMYR PANCHENKo: And the last question. About eight years ago, you said (and not only once) that in 2015 the President of Ukraine will be a graduate of the Kyiv-Mohyla Academy. Some understood your words literally. Petro Poroshenko, however, is not a graduate of the Kyiv-Mohyla Academy... 
VIACHESLAV BRIUKHOVETSKY: I reasoned this by explaining that in 2015 the Kyiv-Mohyla Academy would celebrate its 4ooth anniversary. Several years ago I introduced a clarification: I had in mind not a specific individual, but a generation. Poroshenko, by the way (I haven't looked up his age) could theoretically be a graduate of the Kyiv-Mohyla Academy. We had a first-year student who was 36 years old. When the Academy was created, Petro Poroshenko quite easily could have been our student. I once told Vitaliy Klychko that in theory he could be a graduate of ours. I told Arseniy Yatseniuk the same thing. He replied that he had also thought about the possibility.

We now have 13 Mohyla graduates in the highest of offices, ministers and members of Parliament, and a good number of deputy ministers and first deputy ministers!.. Recently 2 Mohyla graduates were appointed assistant deputy ministers at the Ministry of Finance...

VOLODYMYR PANCHENKO: In short, Mohyla graduates should occupy key positions in all areas of society...

VIACHESLAV BRIUKHOVETSKY: ....and become wealthy. In every sense of the word.

VOLODYMYR PANCHENKO: Thank you for our conversation.

Interview conducted by Volodymyr Panchenko 